\title{
COPPER MOBILITY IN SOILS AS AFFECTED BY SEWAGE SLUDGE AND LOW MOLECULAR WEIGHT ORGANIC ACIDS
}

\author{
L. Bahaminyakamwe, , J. Simunek ${ }^{3}$, J. H. Dane', J. F. Adams', and J. W. Odom²
}

Copper is an essential micronutrient, but at increased concentrations, it quickly becomes toxic to plants, and remediation is needed. Because the land disposal of copper containing sewage sludge is increasing each year, there is a need to evaluate the mobility of copper in soil as affected by sewage sludge and low molecular weight organic acids (citric acid and oxalic acid). Copper mobility was studied in a Marvyn soil (fine-loamy, siliceous, subactive, thermic, Typic Kanhapludult) without or with 1 of 2 sewage sludges from the Birmingham, Alabama area. A total of 5 column experiments were performed. The columns were leached with solutions containing potassium sulfate $\left(10^{-2} \mathrm{M} / \mathrm{L}\right)$ to maintain proper ionic strength, in addition to different combinations of copper, oxalic acid, and citric acid. The $\mathrm{Cu}^{2+}$ concentration in all applied solutions was $1000 \mathrm{mg} \mathrm{Cu}{ }^{2+}$ per $\mathrm{kg}$ of solution. In the column experiments containing sewage sludge, the effluent copper concentration did not reach the influent concentration. In the column experiments without sewage sludge, the influent copper concentrations were easily reached in the effluent, independent of the addition of oxalic or citric acid. A batch equilibrium study showed that both sewage sludges could adsorb more than $50,000 \mathrm{mg}$ of copper per kilogram of sewage sludge, compared with $1250 \mathrm{mg}$ of copper per kilogram of Marvyn soil. This amount is so high that sewage sludges could possibly be used for copper detoxification in mine tailings or farm lands where copper pollution is a potential problem for vegetation. (Soil Science 2006;171:29-38)

Key words: Maximum adsorption, copper, breakthrough curves, HYDRUS-1D, Langmuir isotherms, sewage sludge, mine tailings.

$\mathbf{U}$ NLIKE for other heavy metals, minerals governing $\mathrm{Cu}^{2+}$ solubility in soils are not well known (Lindsay, 1979). Most of the $\mathrm{Cu}^{2+}$ minerals are more soluble than the soil $\mathrm{Cu}$ (copper adsorbed to soil) and will dissolve to form soil $\mathrm{Cu}$ (Lindsay, 1979; Alloway, 1995). Below $\mathrm{pH}$ 6.5, the ion $\mathrm{Cu}^{2+}$ will be the domi-

1Professor, Agronomy and Soils, 201 Funchess Hall, Auburn, AL 36849-5412. E-mail: danejac@auburn.edu

${ }^{2}$ Associate Professors, Agronomy and Soils, 201 Funchess Hall, Auburn, AL 36849-5412.

3Professor, Department of Environmental Sciences, University of California, Riverside, CA

${ }^{4}$ Research Associate, Agronomy and Soils, 201 Funchess Hall, Auburn, AL 36849-5412. Tel. (334)844-4100 Fax (334) 844-3945. Dr. L. Bahaminyakamwe is correspondins author. E-mail: bahamla@auburn.edu

Received May 23, 2005; accepted July 19, 2005.

DOI: 10.1097/01.ss.0000187349.31987.ff nant copper species in soil solution, whereas $\mathrm{CuOH}_{2}^{0}$ is the major solution species above pH 7. The hydrolysis species $\mathrm{Cu}(\mathrm{OH})^{+}$becomes significant between $\mathrm{pH} 6.5$ and 7 . Several $\mathrm{Cu}^{2+}$ complexes, inorganic and organic, also contribute to total copper in soil solution. Sulfate $\left(\mathrm{CuSO}_{4}^{0}\right)$ and carbonate $\left(\mathrm{CuCO}_{3}^{0}\right)$ complexes are important inorganic complexes, because, according to Lindsay (1979), at a concentration of $10^{-2.36} \mathrm{M} \mathrm{SO} \mathrm{S}_{4}^{2-}$, activities of $\mathrm{Cu}^{2+}$ and $\mathrm{CuSO}_{4}^{0}$ are equal, and at $\mathrm{CO}_{2}$ pressure of $0.005 \mathrm{MPa}$, the activities of $\mathrm{CuCO}_{3}^{0}$ and $\mathrm{Cu}(\mathrm{OH})_{2}^{0}$ are equal. The contributions of the other inorganic complexes are negligible, and total inorganic copper in soil solution can be estimated by the following equation (Lindsay, 1979):

$$
\begin{aligned}
{\left[\mathrm{Cu}_{\text {inorg }}\right] } & =\left[\mathrm{Cu}^{2+}\right]+\left[\mathrm{CuOH}^{+}\right]+\left[\mathrm{CuSO}_{4}^{o}\right] \\
& +\left[\mathrm{Cu}(\mathrm{OH})_{2}^{o}\right]+\left[\mathrm{CuCO}_{3}^{o}\right]
\end{aligned}
$$


Reactions controlling $\mathrm{Cu}^{2+}$ in soil solution are similar to those controlling other micronutrients (Tisdale et al., 1993), such as precipitationdissolution, plant absorption-exudation, and immobilization-mineralization. However, adsorption-desorption reactions are of the greatest interest because they most directly affect the levels of copper in the soil solution. Most organic complexes of copper are soluble in water and may not be subject to adsorptiondesorption reactions. To determine if organiccopper complexes are adsorbed to the soil, concentrations of $\mathrm{Cu}^{2+}$ in solution are measured in the presence and the absence of an appropriate organic chelating agent (i.e., oxalic acid, citric acid, and sewage sludge), and the breakthrough curves are compared to establish which organic compound is retarding $\mathrm{Cu}^{2+}$ movement the most. McLaren et al. (1981) found that total solution copper concentrations were increased above equilibrium levels for $\mathrm{Cu}^{2+}$ by the presence of soluble organic complexes. McBride and Blasiak (1979) found that $99.9 \%$ of total soluble $\mathrm{Cu}^{2+}$ was in complexed forms at $\mathrm{pH} 8$. Hodgson et al. (1966) estimated that 99\% of $\mathrm{Cu}^{2+}$ was organically complexed in calcareous soils. Stevenson and Fitch (1981) found that the amount of $\mathrm{Cu}^{2+}$ that can be bound to humic and fulvic acids is equal to the content of acidic groups. This corresponds to the sorption of from 48 to $160 \mathrm{mg}$ of $\mathrm{Cu}^{2+}$ per gram of humic acid (Kabata-Pendias and Pendias, 1992). High sorption of $\mathrm{Cu}^{2+}$ by peat-muck soil and humic acid has been reported (McLaren et al., 1981). Besides humic and fulvic acids, soils contain low molecular weight organic acids such as aliphatic carboxylic, phenolic, and amino acids (Stevenson and Fitch, 1981). These acids are considered soluble, and their presence may maintain $\mathrm{Cu}^{2+}$ in the soil solution. Bloomfield et al. (1976) suggested that $\mathrm{Cu}^{2+}$ may form negatively charged organic complexes not retained by clay minerals. McBride (1981) found that the effects of organic compounds on $\mathrm{Cu}^{2+}$ depend on the nature of the adsorbing surface as well as the type of organic compound. For example, fulvic and glutamic acids were found to enhance $\mathrm{Cu}^{2+}$ adsorption at a given $\mathrm{pH}$, whereas citric acid and EDTA prevented adsorption by maintaining $\mathrm{Cu}^{2+}$ in soil solution (McBride, 1981).

Adsorption and desorption of heavy metal cations are important processes in soils, because they determine the availability of the cations to plants. They also affect the mobility of cations in the soil profile. Excellent reviews have been published describing the adsorption-desorption behavior of heavy metal cations in soils in the presence of organic chelates (Ponizovsky et al., 1999; Temminghoff et al., 1999). Specific adsorption of copper in soils has been evaluated (McLaren and Crawford, 1973; Forbes et al., 1976; McLaren et al., 1981; McBride, 1981). The copper ion is specifically adsorbed by silicate clays, organic matter, iron, aluminum, or manganese oxides. Among all the divalent cations, it is the most strongly held by iron and aluminum oxides (Tisdale et al., 1993). The mechanism of this adsorption is a chemisorption process involving the formation of $\mathrm{Cu}-\mathrm{O}-\mathrm{Al}$ or $\mathrm{Cu}-\mathrm{O}-\mathrm{Fe}$ surface bonds, which is controlled by the quantity of surface $\mathrm{OH}^{-}$groups (KabataPendias and Pendias, 1992; Tisdale et al., 1993). These $\mathrm{OH}^{-}$groups are $\mathrm{pH}$-dependent, and therefore, the adsorption of $\mathrm{Cu}^{2+}$ is a function of $\mathrm{pH}$ (Kabata-Pendias and Pendias, 1992).

In most soils at $\mathrm{pH} 5.5$, copper may be present as specifically adsorbed ions, which are considered to be part of the solid phase. These ions cannot be removed by cation exchange processes when large quantities of other cations are added to the soil (McLaren and Crawford, 1973; Baker and Senft, 1995). The amounts of copper ions which can be removed by exchange reactions will be definitely affected by the $\mathrm{pH}$ of the solution. McLaren et al. (1981) studied the adsorption of copper by individual soil components at equilibrium with copper concentrations normally found in natural soils and concluded that copper adsorption isotherms were essentially linear. They also found that oxides and organic materials adsorbed the greatest amounts of copper. They, however, found little effect on copper adsorption by changes in $\mathrm{pH}$ or background concentrations of cations within the ionic strength and $\mathrm{pH}$ range found in agricultural soils. On the other hand, Sauve et al. (2000 and 2003) found that the partitioning coefficients of copper in organic and inorganic soils were largely predicted by the $\mathrm{pH}$ alone. Polo et al. (1999) studied the effects of sewage sludge on copper adsorption by soils and found that copper adsorption by soils was decreased. In other words, copper remaining in soil solutions was increased in sewage sludge-treated soils despite the low copper concentration in the sewage sludge.

The objectives of this study were to determine (1) the adsorption-desorption of copper in the presence of oxalic acid, citric acid, and 
TABLE 1

Soil physicochemical characterization

\begin{tabular}{lcr}
\hline Analysis & Unit & Values \\
\hline $\mathrm{pH}$ & & 6.6 \\
$\mathrm{P}$ (double acid) & $\mathrm{mg} / \mathrm{kg}$ & 46.0 \\
$\mathrm{Ca}$ (double acid) & $\mathrm{mg} / \mathrm{kg}$ & 150.0 \\
$\mathrm{Mg}$ (double acid) & $\mathrm{mg} / \mathrm{kg}$ & 11.5 \\
$\mathrm{~K}$ (double acid) & $\mathrm{mg} / \mathrm{kg}$ & 60.5 \\
$\mathrm{CEC}$ & $\mathrm{mmol}(+) / \mathrm{kg}$ & 45 \\
Organic matter & $\%$ & 2.6 \\
Particle size & & \\
$\quad$ Sand & $\%$ & 79 \\
Silt & $\%$ & 13 \\
Clay & $\%$ & 8 \\
\hline
\end{tabular}

sewage sludge and (2) the effects of oxalic acid, citric acid, and sewage sludge on the transport parameters of copper using breakthrough curves. The results will improve our understanding of copper retention in biosolid-amended soils and the observed copper detoxification in mine tailings receiving sewage sludge.

\section{MATERIALS AND METHODS}

A Marvyn loamy sand soil (fine-loamy, siliceous, subactive, thermic, Typic Kanhapludult), Ap horizon, from the Auburn Cuellars Rotation experiment (plot 1) was used in this study. The soil $\mathrm{pH}$ was measured using a $\mathrm{pH}$ meter (Beckman Instrument Inc. Model 71) with a combination glass electrode. The measurements were taken $30 \mathrm{~min}$ after mixing $20 \mathrm{~g}$ of dry soil and $20 \mathrm{~mL}$ of deionized water to make a soil/ solution ratio of 1:1 on a weight basis (McLean, 1982). The $\mathrm{pH}$ meter was calibrated with $\mathrm{pH}$ 4- and $\mathrm{pH} 7-$ certified buffers, and the soil samples and water were remixed immediately before a reading was obtained. Particle size analyses were carried out by the Bouyoucos hydrometer method as described by Gee and Or (2002). Exchangeable cations and CEC were determined using $1 \mathrm{NNH}_{4} \mathrm{OAC}$ at $\mathrm{pH} 7$ as described by Thomas (1982). The ammonium concentrations $\left(\mathrm{NH}_{4}^{+}\right)$were determined using the microplate method as described by Sims et al. (1995). The total $\mathrm{NH}_{4}{ }^{+}$contents were used to estimate the CEC of the soil at $\mathrm{pH}$ 7. The soil chemical characterization is summarized in Table 1. Sewage sludges and soil were analyzed for total element composition using the method described by Baker and Amacher (1982). Two grams of soil or sewage sludge was transferred to a porcelain crucible and heated overnight at $450{ }^{\circ} \mathrm{C}$ to destroy organic matter. The ashes were transferred into a $100-\mathrm{mL}$ polypropylene beaker, and $10 \mathrm{~mL}$ of a $30 \% \mathrm{H}_{2} \mathrm{O}_{2}$ solution was added to the beaker and evaporated to dryness at $90{ }^{\circ} \mathrm{C}$. The treatment was repeated until the sample no longer effervesced on addition of $\mathrm{H}_{2} \mathrm{O}_{2}$. Three drops of concentrated $\mathrm{H}_{2} \mathrm{SO}_{4}$ and $10 \mathrm{~mL}$ of a $48 \% \mathrm{HF}$ solution were added to the beaker and evaporated to dryness at $125^{\circ} \mathrm{C}$ in a sand bath. The treatment was repeated twice, then additions of $15 \mathrm{~mL}$ of a concentrated $\mathrm{HNO}_{3}, 2 \mathrm{~mL}$ of concentrated $\mathrm{H}_{2} \mathrm{SO}_{4}$, and $5 \mathrm{~mL}$ of a $60 \% \mathrm{HClO}_{4}$ were made, and the heating continued until strong fumes of $\mathrm{SO}_{3}$ were produced. After cooling the polypropylene beakers, $25 \mathrm{~mL}$ of deionized water was added to complete the extraction of all the elements. Total concentration of copper and other elements was determined by ICP-OES (inductively coupled argon plasma-optical emission spectrophotometry). The results are summarized in Table 2.

\section{Column Experiments}

Figure 1 represents the setup for the column experiments. The column was a Plexiglas cylinder, $30 \mathrm{~cm}$ long with a diameter of $5 \mathrm{~cm}$. The column was filled with the Marvyn soil (columns 1, 2, and 3) at a bulk density of $1.5 \mathrm{~g}$. $\mathrm{cm}^{-3}$. When sewage sludge was used (columns 4 and 5), $200 \mathrm{~g}$ of soil was mixed with $20 \mathrm{~g}$ of sewage sludge, making a ratio of 10:1 soil/ sewage sludge, and the mixture was placed in the bottom quarter of the cylinder (about $7.5 \mathrm{~cm}$ of height). The remaining part of the cylinder was packed with the Marvyn soil. Each column

TABLE 2

Soil and biosolids total elementary analysis

\begin{tabular}{lcrrr}
\hline Analysis & Unit & $\begin{array}{c}\text { Village } \\
\text { Creek waste } \\
\text { water plant }\end{array}$ & $\begin{array}{c}\text { Trussville } \\
\text { waste water } \\
\text { plant }\end{array}$ & Soil \\
\hline Ash & $\%$ & 44.0 & 42.7 & 97.4 \\
Total P & $\mathrm{mg} / \mathrm{kg}$ & 87434.4 & 69754.9 & 191.3 \\
Total Ca & $\mathrm{mg} / \mathrm{kg}$ & 20799.1 & 18758.8 & 1223.7 \\
Total $\mathrm{Mg}$ & $\mathrm{mg} / \mathrm{kg}$ & 4458.6 & 2800.3 & 374.1 \\
Total K & $\mathrm{mg} / \mathrm{kg}$ & 2718.6 & 3710.9 & 1631.8 \\
Total Cu & $\mathrm{mg} / \mathrm{kg}$ & 472.8 & 1413.4 & 2.4 \\
Total Ba & $\mathrm{mg} / \mathrm{kg}$ & 75.5 & 24.1 & 0.2 \\
Total Cd & $\mathrm{mg} / \mathrm{kg}$ & 4.0 & 2.9 & 0.3 \\
Total Co & $\mathrm{mg} / \mathrm{kg}$ & 6.8 & 7.4 & 2.5 \\
Total Cr & $\mathrm{mg} / \mathrm{kg}$ & 58.9 & 34.8 & 5.4 \\
Total $\mathrm{Na}$ & $\mathrm{mg} / \mathrm{kg}$ & 1180.2 & 1200.4 & 83.8 \\
Total $\mathrm{Ni}$ & $\mathrm{mg} / \mathrm{kg}$ & 26.3 & 25.6 & 1.9 \\
Total $\mathrm{Zn}$ & $\mathrm{mg} / \mathrm{kg}$ & 1869.6 & 1146.3 & 8.6 \\
\hline
\end{tabular}




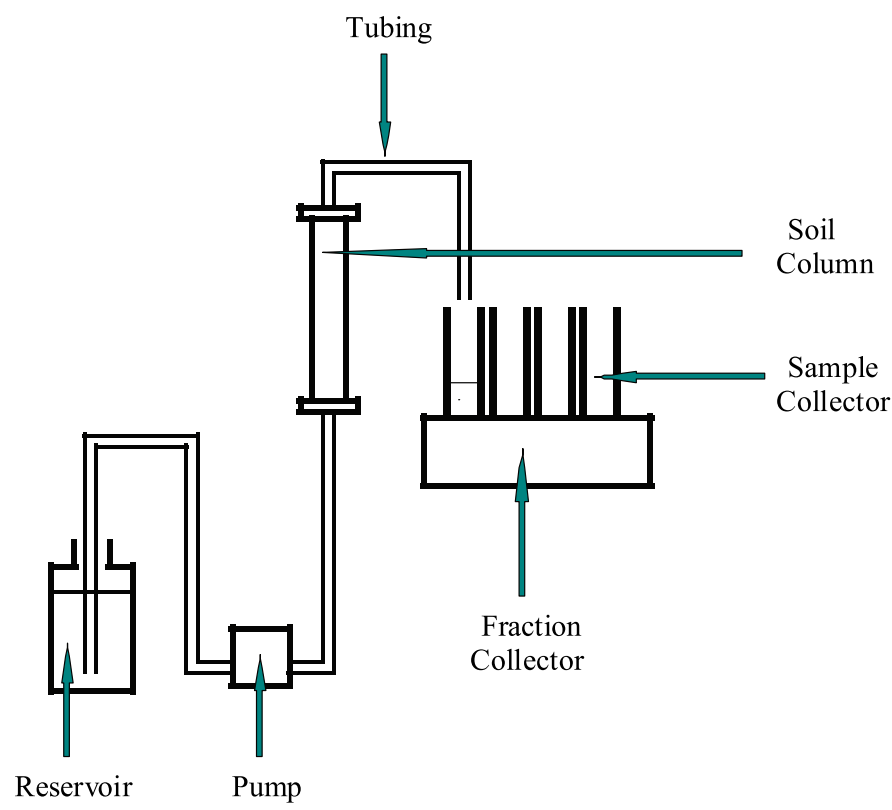

Fis. 1. Schematic representation of the column experiment apparatus.

medium was dry at the start of the experiment. The initial potassium content of the soil and soil/sewage sludge mixtures, as determined by the water extract method, was 29.6 (soil), 54.7 (mixture soil/sewage sludge 1), and $112.6 \mathrm{mg} / \mathrm{kg}$ (mixture soil/sewage sludge 2). Potassium content in the soil sample, as determined in the double-acid method, was $60.5 \mathrm{mg} / \mathrm{kg}$ (Table 1). No copper was detected in the soil sample or the mixtures by the water extract method or the double-acid method (Table 1). The column was leached with a copper solution containing $1000 \mathrm{mg}$ of copper per kilogram of solution $\left(1.57 \times 10^{-2} \mathrm{M} / \mathrm{L} \mathrm{CuSO}_{4}\right)$, and the effluent was collected in sample tubes every $10 \mathrm{~min}$. Oxalic acid $\left(10^{-3} \mathrm{M} / \mathrm{L}\right)$ or citric acid $\left(10^{-3} \mathrm{M} / \mathrm{L}\right)$ was added to the solution only in case that low molecular weight organic acid was needed. Potassium sulfate $\left(10^{-2} \mathrm{M} / \mathrm{L} \mathrm{K}_{2} \mathrm{SO}_{4}\right)$ served as background electrolyte to keep the ionic strength of the effluent solution constant. With a flow rate of $1.2 \mathrm{~mL} / \mathrm{min}$ maintained by a peristaltic pump, $12 \mathrm{~mL}$ of effluent was collected per sample tube and analyzed for $\mathrm{pH}$, copper, and potassium concentrations. The $\mathrm{pH}$ of the effluent samples was determined immediately after the collection of the samples. Copper and potassium were determined using atomic adsorption (AA) and atomic emission using an atomic absorption spectrophotometer, respectively. A breakthrough curve was established for each column, and the retardation factor $R$, the distribution coefficient $K_{\mathrm{d}}$, and the longitudinal dispersivity $D$ were calculated using the HYDRUS-1D software package for simulating one-dimensional movement of water, heat, and multiple solutes in variably saturated media (Simunek et al., 1998). In this study, five column experiments (Table 3) were conducted: (1) the column was packed with Marvyn soil, and the influent solution contained only copper and potassium sulfate; (2) the column was

TABLE 3

Chemical composition of the eluent that was introduced into the medium for the five column experiments

\begin{tabular}{lcccc}
\hline Column no. & $\mathrm{CuSO}_{4}$ & $\mathrm{~K}_{2} \mathrm{SO}_{4}$ & Oxalic acid & Citric acid \\
\hline 1 & $1.57 \times 10^{-2} \mathrm{M} / \mathrm{L}$ & $10^{-2} \mathrm{M} / \mathrm{L}$ & $\mathrm{NA}$ & $\mathrm{NA}$ \\
2 & $1.57 \times 10^{-2} \mathrm{M} / \mathrm{L}$ & $10^{-2} \mathrm{M} / \mathrm{L}$ & $10^{-3} \mathrm{M} / \mathrm{L}$ & $\mathrm{NA}$ \\
3 & $1.57 \times 10^{-2} \mathrm{M} / \mathrm{L}$ & $10^{-2} \mathrm{M} / \mathrm{L}$ & $\mathrm{NA}$ & $10^{-3} \mathrm{M} / \mathrm{L}$ \\
4 & $1.57 \times 10^{-2} \mathrm{M} / \mathrm{L}$ & $10^{-2} \mathrm{M} / \mathrm{L}$ & $\mathrm{NA}$ & $\mathrm{NA}$ \\
5 & $1.57 \times 10^{-2} \mathrm{M} / \mathrm{L}$ & $10^{-2} \mathrm{M} / \mathrm{L}$ & $\mathrm{NA}$ & $\mathrm{NA}$ \\
\hline
\end{tabular}


packed with Marvyn soil, and the influent contained oxalic acid in addition to copper and potassium sulfate; (3) the column was packed with Marvyn soil, and the influent contained citric acid in addition to copper and potassium sulfate; (4) the bottom quarter of the column was packed with a mixture of the Marvyn soil and sewage sludge 1 (Village Creek waste water plant in Birmingham, AL); and (5) the bottom quarter of the column was packed with a mixture of the Marvyn soil and sewage sludge 2 (Trussville waste water plant in Trussville, $\mathrm{AL})$. The influent solution in column experiments 4 and 5 contained only copper and potassium sulfate.

\section{Sorption Isotherm}

To determine how much copper can be adsorbed by the sewage sludges and by the Marvyn soil, a series of batch experiments was conducted. Triplicate $10-\mathrm{g}$ samples were prepared of oven-dried $\left(105^{\circ} \mathrm{C}\right)$ sewage sludge 1 , oven-dried sewage sludge 2 , and oven-dried Marvyn soil for each of 9 copper concentrations, resulting in a total of 81 samples. Each sample was placed in a $125-\mathrm{mL}$ Erlenmeyer flask, and copper was added to each replicate set in the following amounts: $0,1,2,4,8,10,20,40$, and $80 \mathrm{mg}$. Deionized water was then added to bring the total volume in each flask to $100 \mathrm{~mL}$. The flasks were secured on a reciprocal mechanical shaker and shaken overnight for equilibration purpose. The contents of the flasks were filtrated through Whatman no. 42 filter paper, and the copper concentration of the filtrates was determined by AA. Amounts of copper adsorbed on the soil or on the sewage sludge were calculated from the difference between the initial copper concentrations and the equilibrium aqueous phase concentrations of copper. Because sewage sludges adsorbed so much copper, 5 additional copper concentrations were added only to the sewage sludges, resulting in the following amounts of copper being added to triplicate $10-\mathrm{g}$ samples of oven-dried sewage sludges: 100, 200, 400, 800, and $1000 \mathrm{mg}$. The same procedure was used to determine the amounts of copper adsorbed.

\section{RESULTS AND DISCUSSIONS}

The $\mathrm{pH}$ values of the samples collected during each column experiment were immediately determined and are presented in Fig. 2. Zero time for all column experiments is defined as the time at which the first drop of the effluent appeared (1 pore volume of effluent is equivalent to $200 \mathrm{~min}$ of leaching). Although initial $\mathrm{pH}$ values for all columns differed somewhat, they were close to the $\mathrm{pH}$ of the Marvyn soil $\mathrm{pH}$ (6.6). First, there was a slight increase in $\mathrm{pH}$, suggesting that some $\mathrm{H}^{+}$ions were adsorbed by the column medium, followed by a steady decrease. This might be the result of the lack of equilibrium observed at the beginning of many column experiments, particularly when the medium in the column was not saturated by a background solution. At the end of each column experiment (10 pore volumes of effluent), the $\mathrm{pH}$ values of the collected effluent samples were

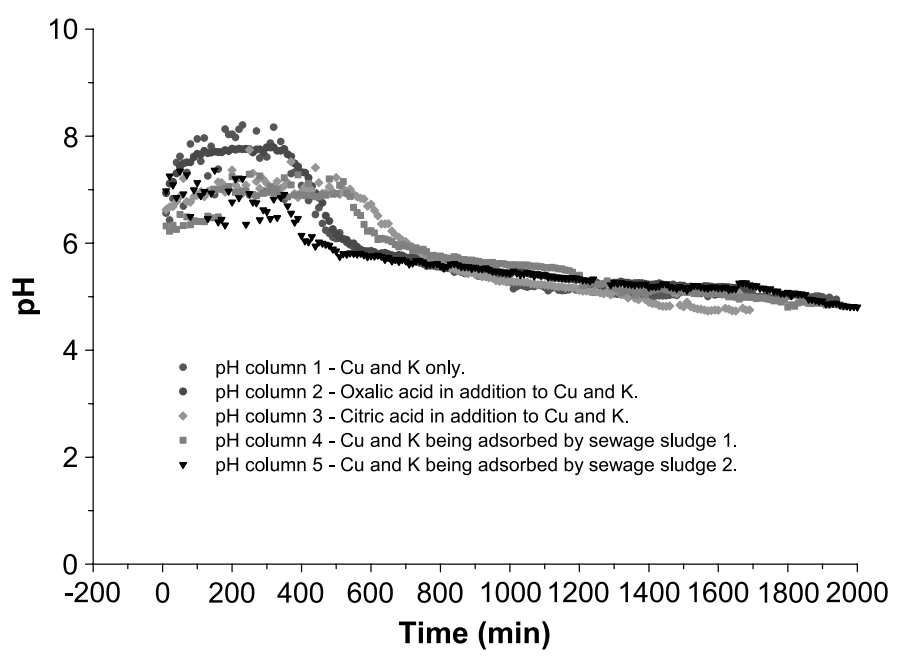

Fig. 2. Changes in $\mathrm{pH}$ value of the effluent as time (leaching volume) progresses. 
TABLE 4

Values of the distribution coefficient $\left(K_{\mathrm{d}}\right)$, the retardation factor $(R)$, the longitudinal dispersivity $(D)$, and the regression coefficient $\left(r^{2}\right)$ for copper $(\mathrm{Cu})$ and potassium $(\mathrm{K})$ as estimated by HYDRUS-1D

\begin{tabular}{|c|c|c|c|c|}
\hline Column no. & $K_{\mathrm{d}}$ & $R$ & $\mathrm{D}(\mathrm{cm})$ & $r^{2}$ \\
\hline \multicolumn{5}{|l|}{$\mathrm{Cu}$} \\
\hline 1 (100\% Soil) & 1.26 & 5.26 & 3.04 & 0.980 \\
\hline $2(100 \%$ Soil $)$ & 1.26 & 5.24 & 2.81 & 0.991 \\
\hline 3 (100\% Soil) & 1.41 & 5.74 & 1.17 & 0.990 \\
\hline 4 (75\% Soil) & $1.26^{\dagger}$ & $5.26^{\dagger}$ & $3.04^{\dagger}$ & NA \\
\hline$(25 \% \text { Mixture })^{*}$ & 5.85 & 16.95 & 13.06 & 0.992 \\
\hline 5 (75\% Soil) & $1.26^{\dagger}$ & $5.26^{\dagger}$ & $3.04^{\dagger}$ & NA \\
\hline (25\% Mixture) & 5.46 & 15.85 & $30.00^{\S}$ & 0.992 \\
\hline \multicolumn{5}{|l|}{$\mathrm{K}$} \\
\hline 1 (100\% Soil) & 0.13 & 1.42 & 0.83 & 0.977 \\
\hline 2 (100\% Soil) & 0.17 & 1.56 & 2.07 & 0.949 \\
\hline 3 (100\% Soil) & 0.16 & 1.53 & 1.15 & 0.974 \\
\hline $4(75 \%$ Soil $)$ & $0.13^{\dagger}$ & $1.42^{\dagger}$ & $0.83^{\dagger}$ & NA \\
\hline (25\% Mixture) & 0.63 & 2.72 & $30.00^{\S}$ & 0.935 \\
\hline 5 (7\% Soil) & $0.13^{\dagger}$ & $1.42^{\dagger}$ & $0.83^{\dagger}$ & NA \\
\hline (25\% Mixture) & 0.56 & 2.52 & $30.00^{\S}$ & 0.927 \\
\hline
\end{tabular}

${ }^{\dagger}$ These values were not optimized. They were fixed to values obtained by the optimization in column 1 .

*The mixture consisted of sewage sludge and the Mavyn soil in the ratio of $1: 10$.

${ }^{\S}$ These values were constrained to the value of the length of the column.

very close to the $\mathrm{pH}$ value of the influent solution ( $\mathrm{pH}$ 4.7).

Potassium, which was used to maintain a constant ionic strength, was hardly retarded by the soil or sewage sludge, and the maximum (influent) potassium concentration was quickly obtained (Table 4; Fig. 3). This was in part attributed to the potassium already present in soil and in part to the lower valence of $\mathrm{K}^{+}$ compared with $\mathrm{Cu}^{2+}$. This may have been different if a $\mathrm{Ca}^{2+}$ or $\mathrm{Al}^{3+}$ solution had been used to maintain a constant ionic strength. According to Cavallaro and McBride (1978), $\mathrm{Ca}^{2+}$ greatly reduces the efficiency of heavy metal adsorption, suggesting a stronger $\mathrm{Ca}^{2+}$ than $\mathrm{K}^{+}$affinity for adsorption sites.

When the influent contained only copper and potassium sulfate (column 1), the breakthrough curve (Fig. 4) showed that copper detection in the effluent occurred $400 \mathrm{~min}$ after the start of the experiment (about 2 pore volumes of effluent). Maximum copper concentration was obtained $1600 \mathrm{~min}$ after the start of the experiment (about 8 pore volumes). When the eluent contained oxalic acid (column 2) in addition to copper and potassium sulfate, the breakthrough curve (Fig. 4) resembled the one obtained when copper and potassium sulfate alone were present in the eluent solution. Apparently, oxalic acid did not affect copper movement in the soil. When the eluent contained citric acid (column 3 ) in addition to copper and potassium sulfate, the breakthrough curve (Fig. 4) showed that copper detection in the effluent happened $600 \mathrm{~min}$ after the start of the experiment (about 3 pore volumes). Citric acid affected copper movement by increasing the retardation factor (Table 4). However, the maximum copper concentration was obtained $1600 \mathrm{~min}$ after the start of the column experiment (about 8 pore volumes), which was the same time observed for the maximum copper concentration when copper was alone or mixed

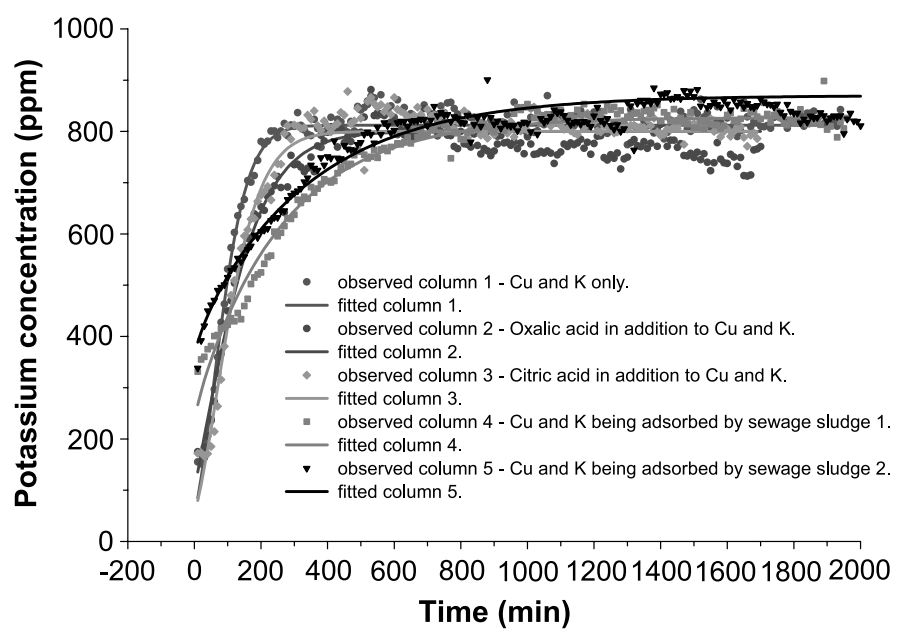

Fig. 3. Breakthrough curves for $\mathrm{K}^{+}$in columns 1 to 5 . 


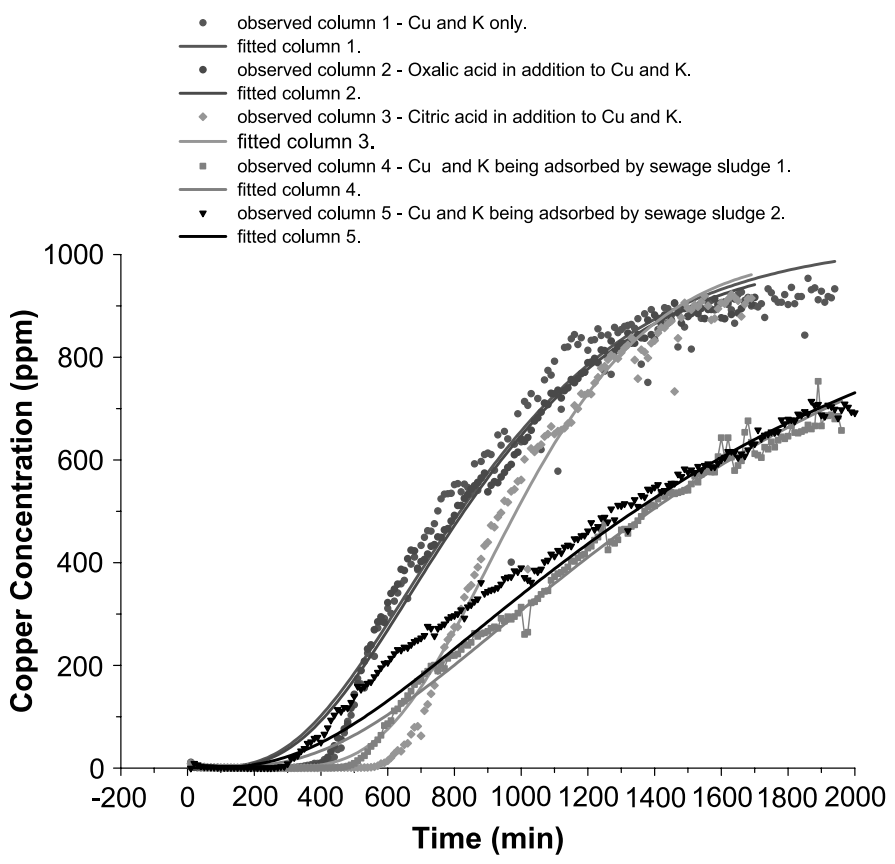

Fig. 4. Breakthrough curves for $\mathrm{Cu}^{2+}$ in columns 1 to 5 .

with oxalic acid in the eluent solution. Bineyev et al. (1982) found that copper adsorption by soil or sewage sludge was $64 \%$ higher when copper was used alone in solution than when copper was added in a mixture of amino acids. This was the case when copper was used in a mixture with oxalic acid, but when copper was present in a mixture with citric acid, it was shown that citric acid formed stronger complexes with copper than oxalic acid or amino acids, and the retardation factor was higher than the ones obtained in the first two column experiments. The use of sewage sludge 1 (column 4) showed a threefold increase in $R$ over the previous

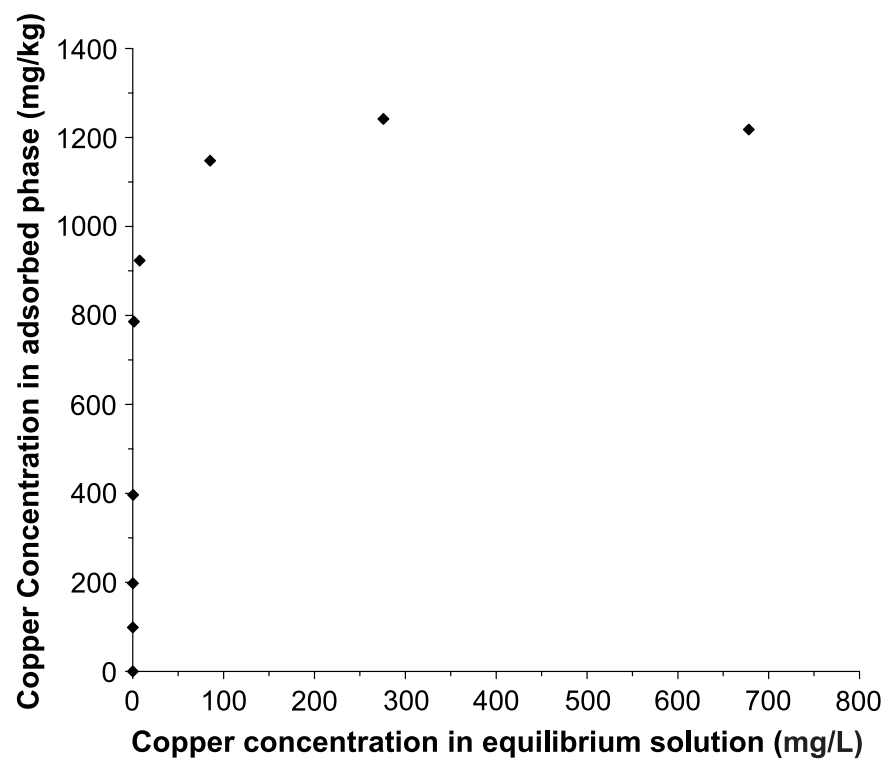

Fig. 5. Langmuir adsorption isotherm when $\mathrm{Cu}^{2+}$ is being adsorbed by the Marvyn soil. 
3 column experiments (Table 4). Copper was first detected in the effluent 500 min (about 2.5 pore volumes) after the start of the experiment, the same time as when no sewage sludge was used, but the maximum copper concentration was not yet obtained $2000 \mathrm{~min}$ (about 10 pore volumes) after the start of the experiment (Fig. 4). In case of sewage sludge 2 (column 5), detection of copper in the effluent first happened $300 \mathrm{~min}$ after the start of the experiment (Fig. 4), which is $200 \mathrm{~min}$ earlier than with sewage sludge 1 (column 4). However, the retardation factor $R$ (Table 4) was almost the same as for sewage sludge 1 (16.95 for sewage sludge 1 and 15.85 for sewage sludge 2). Like in case of sewage sludge 1, the maximum copper concentration was not obtained $2000 \mathrm{~min}$ after the start of the experiment (about 10 pore volumes).

Not reaching the maximum copper concentration for both sewage sludges is an indication that sewage sludges adsorb a large quantity of copper and potentially other heavy metals. Bergkvist and Jarvis (2004) found that soils amended with sewage sludge have a very high adsorption capacity with regard to cadmium. Liu and Wang (2004) studied in situ speciation of copper-humic substances in a contaminated soil during electrokinetic remediation and found that copper-humic substances were associated with $50 \%$ of the total copper contained in the soil. To check how much copper could be adsorbed by the sewage sludge, a Langmuir adsorption isotherm was determined for the soil (Fig. 5) and the sewage sludges (Fig. 6). The maximum adsorption of copper for the soil was $1250 \mathrm{mg} / \mathrm{kg}$. In case of the sewage sludges, the maximum copper adsorption was $50,000 \mathrm{mg} / \mathrm{kg}$, which is 40 times higher than the soil maximum adsorption of copper. Both sewage sludges adsorbed the same amount of copper. This is an indication that these sewage sludges have the same amount of copper adsorption sites and could be used to detoxify copper from mine tailings because they adsorb so much copper. Over time, however, the decomposition of sewage sludge may be followed by copper desorption. Keeping the $\mathrm{pH}$ of the soil around $\mathrm{pH} 6.5$ by liming would lower copper availability to plants and minimize the risk of leaching. Addition of organic matter would maintain copper in an organic form that would be less available to plants or leaching.

\section{CONCLUSION}

In general, copper adsorption by soils is affected by soil organic matter content. The presence of low molecular weight organic acids and sewage sludge in soils might prevent copper adsorption by forming soluble copper complexes. In this study, oxalic acid-copper complexes did not affect the mobility of copper in a Marvyn loamy sand. Citric acid-copper complexes, however, retarded the mobility of copper in the same

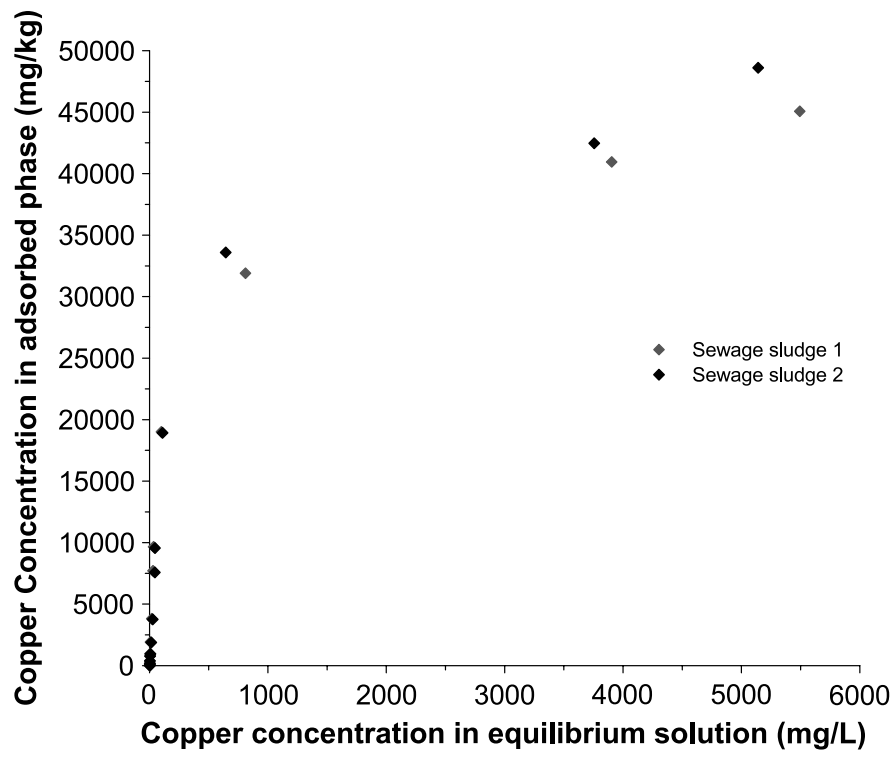

Fig. 6. Langmuir adsorption isotherm when $\mathrm{Cu}^{2+}$ is being adsorbed by the sewage sludges 1 and 2. 
soil. Adding sewage sludge to the soil greatly slowed the mobility of copper in the column medium. The maximum (influent) copper concentration was not yet obtained $2000 \mathrm{~min}$ (about 10 pore volumes of the influent) after the start of the experiment. The maximum copper adsorption was determined to be $1250 \mathrm{mg} / \mathrm{kg}$ and $50,000 \mathrm{mg} / \mathrm{kg}$ for the soil and sewage sludges, respectively. With this amount being adsorbed, sewage sludges could be used to detoxify copper in soils and mine tailings.

Heavy metals such as $\mathrm{Cu}^{2+}$ are known to be adsorbed by soil organic matter in large amounts (Lehmann and Harter, 1984). Sewage sludge provides abundant organic matter, and its utilization as land applied amendment is limited mostly by the heavy metals content (Polo et al., 1999). The fact that sewage sludge adsorbs large amounts of heavy metals, as demonstrated by this study, should be one of the factors in favor of more use of sewage sludge as a heavy metal detoxifier. Unfortunately, because of the heavy metal load already present, the adsorption of heavy metals could be rendered ineffective by the release with time of excess heavy metals. The fear of sewage sludge releasing heavy metals considered toxic to the environment has caused the EPA to establish regulations for sewage sludge use in the environment.

\section{REFERENCES}

Alloway, B. J. 1995. Soil processes and the behavior of metals. In: Heavy Metals in Soils. 2nd ed. B. J. Alloway (ed.). Blackie Academic and Professional, London, U.K., pp. 11-37.

Baker, D. E., and J. P. Senft. 1995. Copper. In: Heavy Metals in Soils. 2nd ed. B. J. Alloway (ed.). Blackie Academic and Professional. London, U.K., pp. 179-205.

Baker, D. E., and M. C. Amacher. 1982. Nickel, copper, zinc and cadmium. In: Methods of Soil Analysis. Part 2. 2nd ed. A. L. Page (ed.). Soil Sci. Soc. Amer. Madison, WI, pp. 323-336.

Bergkvist, P., and N. Jarvis. 2004. Modeling organic carbon dynamics and cadmium fate in long-term sludge-amended soil. J. Environ. Qual. 33:181-191.

Bineyev, R. G., F. K. Khabibullin, A. I. Sharyapova, and B. R. Grigoryan. 1982. Effect of chelating agents on the absorption of copper by plants. Translated from: Pochvovedeniye. 11:34-37.

Bloomfield, C., W. I. Kelso, and G. Pruden. 1976. Reactions between heavy metals and humidified organic matter. J. Soil Sci. 27:16-31.

Cavallaro, N., and M. B. McBride. 1978. Copper and cadmium adsorption characteristics of selected acid and calcareous soils. Soil Sci. Soc. Am. J. 42: 550-556.

Forbes, E. A., A. M. Posner, and J. P. Quirk. 1976. The specific adsorption of divalent $\mathrm{Cd}, \mathrm{Co}, \mathrm{Cu}$, $\mathrm{Pb}$, and $\mathrm{Zn}$ on goethite. J. Soil Sci. 27:154-166.

Gee, G. W., and D. Or. 2002. Particle size analysis. In: Methods of Soil Analysis: Physical Methods. Part 4. J. H. Dane and G. C. Topp (co-eds.). No. 5. Soil Sci. Soc. Amer. Madison, WI, pp. 255-293.

Hodgson, J. F., W. L. Lindsay, and J. F. Trierweiler. 1966. Micronutrient cation complexes in soil solution: II. Complexing of zinc and copper in displaced solution from calcareous soils. Soil Sci. Soc. Am. Proc. 30:723-726.

Kabata-Pendias, A., and H. Pendias. 1992. Trace Elements in Soils and Plants. 2nd ed. CRC Press, Boca Raton, FL.

Lehmann, R. G., and R. Harter. 1984. Assessment of copper-soil bond strength by desorption kinetics. Soil Sci. Soc. Am. J. 48:769-772.

Lindsay, W. L. (ed.). 1979. Chemical Aquilibria in Soils. Wiley-Interscience, New York.

Liu, S. H., and H. P. Wang. 2004. In situ speciation studies of copper-humic substances in a contaminated soil during electrokinetic remediation. J. Environ. Qual. 33:1280-1287.

McBride, M. B. 1981. Forms and distribution of copper in solid and solution phases of soil. In: Copper in Soils and Plants. J. F. Loneragan, A. D. Robson, and R. D. Graham (eds.). Academic Press, New York, pp. 25-45.

McBride, M. B., and J. J. Blasiak. 1979. Zinc and copper solubility as a function of $\mathrm{pH}$ in an acid soil. Soil Sci. Soc. Am. J. 43:866-870.

McLaren R. G., and D. V. Crawford. 1973. Studies on soil copper. II. The specific adsorption of copper by soils. J. Soil Sci. 24:443-452.

McLaren, R. G., R. S. Swift, and J. G. Williams. 1981. The adsorption of copper by soil materials at low equilibrium solution concentrations. J. Soil Sci. 32:247-256.

McLean, E. O. 1982. Soil $\mathrm{pH}$ and lime requirement. In: Methods of Soil Analysis. Part 2. 2nd ed. A. L. Page (ed.). Soil Sci. Soc. Amer. Madison, WI, pp. 199-224.

Polo, M. J., R. Ordonez, and J. V. Giraldez. 1999. Copper and zinc adsorption by sewage sludgetreated soil in Southern Spain. Commun. Soil Sci. Plant Anal. 30:1063-1079.

Ponizovsky, A. A., T. A. Studenikina, and E. V. Mironenko. 1999. Copper retention as affected by complex formation with tartaric and fulvic acids. In: Fate and Transport of Heavy Metals in the Vadose Zone. H. M. Selim and I. K. Iskandar (eds.). Lewis Publishers, Boca Raton, FL, pp. 107-125.

Sauvé, S., W. Hendershot, and H. E. Allen. 2000. Solid-solution partitioning of metals in contaminated soils: dependence on $\mathrm{pH}$, total metal burden, and organic matter. Environ. Sci. Technol. 34: $1125-1131$. 
Sauvé, S., S. Manna, M. C. Turmel, A. G. Roy, and F. Courchesne. 2003. Solid-solution partitioning of $\mathrm{Cd}, \mathrm{Cu}, \mathrm{Ni}, \mathrm{Pb}$, and $\mathrm{Zn}$ in the organic horizons of a forest soil. Environ. Sci. Technol. 37:5191-5196.

Sims, G. K., T. R. Ellsworth, and R. L. Mulvaney. 1995. Microscale determination of inorganic nitrogen in water and soil extracts. Comm. Soil Sci. Plant Anal. 26:303-316.

Simunek, J., M. Sejna, and M. Th. Van Genuchten. 1998. The HYDRUS-1D software package for simulating the one-dimension movement of water, heat, and multiple solutes in variably-saturated media. Version 2.0, IGWMC-TPS-70. International Ground Water Modeling Center, Colorado School of Mines, Golden, CO.

Stevenson, F. J., and A. Fitch. 1981. Reactions with organic matter. In: Copper in Soils and Plants. J. F. Loneragan, A. D. Robson, and R. D. Graham (eds.). Academic Press, New York, pp. 69-65.

Temminghoff, E. J. M., M. P. J. C. Marinussen, and S. E. A. T. M. Van Der Zee. 1999. Copper mobility and bioavailability in relation with chemical speciation in sandy soil. In: Fate and Transport of Heavy Metals in the Vadose Zone. H. M. Selim and I. K. Iskandar (eds.). Lewis Publishers, Boca Raton, FL, pp. 127-146.

Tisdale, S. L., W. L. Nelson, J. D. Beaton, and J. L. Havlin. 1993. Soil Fertility and Fertilizers. 5th ed. McMillan Publishing Co, New York.

Thomas, G. W. 1982. Exchangeable cations. p. 159165. In: Methods of Soil Analysis. Part 2. 2nd ed. A. L. Page (ed.). Soil Sci. Soc. Amer. Madison, WI. 